\title{
Study on Portulaca Oleracea Native Species as Vegetal Source of Omega-3 and 0mega-6 Fatty Acids
}

\author{
CANDICE POPESCU (POPINIUC) ${ }^{1,5}$, CARMEN POPESCU2, 3*, STEFAN MANEA2 ${ }^{2}$, VALENTIN VLADUT ${ }^{4}$, IOAN CABA $^{4}$, \\ ILEANA CRISTINA COVALIU ${ }^{6}$, HAZEM ABBAS ${ }^{1}$, ALINA DUNE², DUMITRU LUPULEASA ${ }^{1}$ \\ 'University of Medicine and Pharmacy Carol Davila, Faculty of Pharmacy, 8 Eroii Sanitari Str., 050474, Bucharest, Romania \\ ${ }^{2}$ S.C. HOFIGAL Export Import S.A., 2 Intrarea Serelor, 061151, Bucharest, Romania \\ 3Faculty of Pharmacy, Vasile Goldis Western University, 94 Revolutiei Blvd., 310025, Arad, Romania \\ ${ }^{4}$ National Institute of Research-Development for Machines and Installations Designed to Agriculture and Food Industry, INMA, \\ 6 Ion Ionescu de la Brad Blvd., 013813, Bucharest, Romania \\ ${ }^{5}$ Innergy (SC INNER Chi Nature srl), Voluntari, Romania \\ ${ }^{6}$ University Politehnica of Bucharest, Faculty Biotechnical Systems Engineering, 313 Splaiul Independentei, 060042, Bucharest, \\ Romania
}

\begin{abstract}
Fatty grass, grasita or purslane (Portulaca oleracea L.) is an important plant identified as a natural weed in field crops and lawns. Purslane is widespread worldwide and is popular as edible plants in many areas of Europe, Asia and the Mediterranean region. This plantpossesses mucilaginous substances of great medicinal importance. It is a rich source of potassium, magnesium and calcium and has the potential to be used as a vegetal source of omega-3 and omega-6. It is very good as a source of alpha-linolenic acid (ALA) and gamma-linolenic acid (GLA) and contains the highest amount compared to any other green leafy vegetables. It also contains significant amounts of alpha-tocopherol and ascorbic acid, as well as an increased content of oxalate in fresh leaves. The antioxidant value and nutritional content of purslane are important for human consumption. It reveals a huge nutritional potential and indicates the potential for future use of this plant in food industry, dietary supplements, drugs, cosmetics and products for body care.
\end{abstract}

Keywords: Portulaca Oleracea, omega-3, omega-6

Purslane (Portulaca oleracea L.) deserves a special attention from farmers, nutritionists, doctors and other categories of researchers from the pharmaceutical industry, food supplements and cosmetics.Purslane is a common plant in areas of grass, lawn, and in field crops. Many varieties of purslane, which is known under several names, grow in a wide range of climates and regions. Purslane has a wide acceptability in Central Europe, Asia and the Mediterranean region. It is an important component as lettuce, and the fresh stem and young leaves are used raw, alone or in combination with other herbs. Purslane is also used for cooking or as pickes [1-3].

Its medicinal value is evident from its use in the treatment of burns, headaches, and also in diseases related to the gut, liver, stomach, cough, shortness of breath and arthritis, use as a purgative, cardiac tonic, emollient, muscle relaxant and anti-inflammatory treatment and diuretic, all of these making purslane important in herbal based medicine.Purslane was also used to treat osteoporosis and psoriasis. Recent research has demonstrated that the purslane has much better nutritional quality than the main vegetables, with a higher amount of beta-carotene, ascorbic acid and alpha-linolenic acid. In addition, purslane was described as a consistent food due to its high nutritive and antioxidant characteristics [4-8].

Different varieties, harvesting methods and environmental conditions can contribute to the composition and nutritional benefits of purslane. Purslane is popular in traditional Chinese medicine, to treat diabetes and arterial hypotension. From a scientific perspective, it was not proved to have anti-diabetic effect, but still people are using it for this purpose. An experiment was conducted to extract the raw polysaccharides in purslane to investigate the hypoglycaemic effects of these constituents with animal testing for the use of this plant in the treatment of diabetes [9-13].

Purslane is a good source of alpha-linolenic acid. Alphalinolenic acid is an omega-3 fatty acid, which plays an important role in human growth and developmentand also in disease prevention. Purslane has been proved to contain a five times higher amount of Omega- 3 andOmega- 6 fatty acids, compared to the spinach. Fatty acids Omega- 3 and Omega- 6 belong to a group of polyunsaturated fatty acids that are essential for human growth, development, prevention of various cardiovascular diseases and maintaining of a healthy immune system.

The human body does not synthesize Omega-3 fatty acids. Therefore, the Omega-3 fatty acids must be consumed from an exogenous food source. Omega-3 fatty acids contain 18 to 24 carbon atoms and they have three or more double bonds in its chain of fatty acids. Omega-3 fatty acids are part of the family of polyunsaturated long chain fatty acids of carbon atoms and are represented by alpha-linoleic acid (ALA), eicosapentaenoic acid (EPA) and docohexanoic acid (DHA). Alpha-linolenic acid is considered essential as it can not be synthesized by the organism, the main source for obtaining it being the food. ALA may be converted in the body to EPA and DHA but the amounts are insignificant (less than 5\%) [14-18].

Omega-6 is another class of polyunsaturated fatty acids comprising the linoleic acid (LA), gamma-linolenic acid (GLA) and arachidonic acid (ARA). LA is the main Omega6 in the food, corn oil and and sunflower oil having the highest content; it is still considered an essential fatty acid because it cannot be synthesized in the body. Except for the human milk, most foods contain very little active GLA. ARA is found in meat and eggs. In the human body, Omega6 fatty acids, especially the linoleic acid, are converted to

\footnotetext{
*email: popescu_carmen88@yahoo.com
} 
arachidonic acid, which is embedded in the cell membranes [19-21].

There has been much debate among the nutritionists regarding the harmful effects of Omega- 6 fatty acids, assuming that they would promote inflammation (because the arachidonic acid is involved in the early stages of inflammation) and thus would increase the cardiovascular risk. However, the linoleic acid generates antiinflammatory molecules. Thus, at the level of the vascular endothelium, Omega-6 fatty acids have anti-inflammatory properties, suppressing the production of adhesion molecules, chemokines, and interleukins, which are the key mediators of the process of atherosclerosis [22-25].

Purslane has been identified as one of the richest vegetal sources of al pha-linolenic acid, an Omega-3 essential fatty acid. The lack of food sources of Omega-3fatty acids led to a growing interest to enter purslane as a new cultivated vegetable. Purslane flourishes in numerous biogeographical locations around the world and is highly adaptable to many adverse conditions, such as drought, saline solution and nutrient deficient conditions.

Purslane (Portulaca oleracea) is an annual plant of the Portulacaceae family, native to Southern Europe and Middle East. In Romania it is also known as grasita. It was mentioned by Dioscoride in the list of medicinal plants used by the Gauls, by the name of lax. It is a plant with root systems, with cylindrical and firm stem, fleshy, creeping, but it is also able to develop erect stems, often with a reddish shade, reaching lengths of $10-40 \mathrm{~cm}$. The leaves are thick, spatulate, narrowed to the base, glossy, dark green.The flow ers are small, generally in yellow colored, but they can also be orange or reddish shaded. The fruit is a capsule with numerous gray colored small seeds. In a gram are contained about 2,400 seeds. A seed retains its germination properties for 3-4 years. The plant prefers light, sandy soils, rich in nutrients, located in warm areas of the world, and also in temperate or cold areas. It grows wild or cultivated in Europe, America and Asia.

The origin of purslane is uncertain, but the existence of this plant is reported as early as 4.000 years ago. Succulent stems and fleshy leaves of purslane demonstrates that it may have originated and can adapt to the desert climate of the Middle East and India. It can be found in Europe, Africa, North America, Australia and Asia. Portulaca oleracea is a cosmopolitan species and the portulaca genus belongs to the Portulacaceae family, which is a small family with 21 genus and 580 species, occurring especially in America and with some species identified in the Arab countries.

Purslane are succulent, an annual herbaceous plants, erectile or creeping, up to $30 \mathrm{~cm}$ height. Purslane is known under the botanical name Portulaca oleracea and is also called Portulaca. It grows well in orchards, vineyards, crop fields, landscaped areas, gardens, roadsides, and other spontaneous sites. The stems are cylindrical, up to $30 \mathrm{~cm}$ in length, 2-3 $\mathrm{mm}$ in diameter, green or red colored, developed in nodes, smooth, except for the underarms of the leaves, stems branched, and the distance between nodes is $1.5-3.5 \mathrm{~cm}$ in length [26-28].

The leaves are alternately or superimposed, flat, fleshy, having variable shapes, obovate, with a length of $1-5 \mathrm{~cm}$, obtuse or slightly notched at the tip, tapered at the base, smooth and coated on the upper surface, with full edges. The leaves are in the form of a spatula, succulent, with very short stems, about $5-30 \mathrm{~mm}$ in length, and they are green or green with red border.The blooming period is initiated in May and extends until September. Flowers are single or clusters of two to five to the top. The flowers are small, with colors of orange, pink, yellow, purple or white, with five petals and they are usually opened only in warm and sunny days from mid-morning to early afternoon. Fruits are formed by egg-shaped capsules, almost rounded, approximately $4-8 \mathrm{~mm}$ in length and they open in the middle to release the seeds. The seeds are small, less than $1 \mathrm{~mm}$ in diameter, flattened, brown to black, with a white point of attachment. Many seeds are produced.

The health benefits of purslane are due to its nutritional value and content in unsaturated fatty acids. It is rich in vitamin $A$, which is a natural antioxidant asset. The presence of this vitamin may play an important role in the health of the mucous membranes, for the protection against lung cancer and mouth cavity. Purslane has one of the highest content of vitamin A among the vegetables with green leaves. It also contains vitam in $C$ and $B$ vitamins such as riboflavin, niacin, and pyridoxine. This provides large amounts of food minerals such as potassium, magnesium, calcium, phosphorus and iron.0mega-3 fatty acids: purslane is one of the richest sources of green plants in Omega-3. Its consumption determines lower values of cholesterol and triglycerides, and also the increase of beneficial high-density lipoproteins.Moreover, the ability to provide Omega-3 fatty acids leads to reduced atheroma and may be advantageous in the treatment of vascular diseases. Omega-3 fatty acids are important nutrients for the body, in particular for the maintenance of cardiovascular health. Often recommended for their antiinflammatory and anticoagulant properties, Omega-3 healthy fats reduce considerably the onset risk of heart disease or heart attack triggering.

Most people associate the benefits of Omega-3 fatty acids with a healthy heart, but they have many key roles in the body. For example, they are importantfor brain function, improved mood, memory, joint mobility, reduce inflammation caused byarthritis, protection of vision health, strengthen the immune system and maintain hair, skin and nails in optimal shape.

The most important fatty acids in the nutritional point of view, in the category of Omega-3 essential fats are the alpha-linolenic acid (ALA), eicosapentaenoic acid (EPA) and docosahexaenoic acid (DHA). Alpha-linolenic acid is among the fatty acids classified as essential, because it can not be produced by the body and plays a basic role in many physiological functions. The body converts the alphalinolenic acid to two important Omega-3 fats, namely the eicosapentaenoic acid and docosahexaenoic acid. These two derivatives acids can also be derived from certain foods, such as the species of cold water fish (salmon, tuna, halibut or herring). The eicosapentaenoic acid plays an important role in preventing the cardiovascular disease, while the docosahexaenoic acid is required for proper development of the brain and nervous system. Unlike fish oils with high cholesterol and caloric content, purslane also provide an excellent source of beneficial Omega-3 fatty acids, cholesterol-free as those in fish oils.

\section{The role of Omega-3 fatty acids in the body}

Each cell of the body is surrounded by a cell membrane, primarily composed of fatty acids. It regulates the necessary level of nutrients that get inside the cell and facilitates the elimination of residual products. To fulfill its functions optimally, the cell membrane must maintain its integrity and fluidity (diseased membrane cells lose their ability to retain water and vital nutrients, and to promptly communicate with other cells). Since the structure of cell membrane is composed mostly of fats, the Omega- 3 fatty acids are directly involved in the longevity of the body's cells. 
Another important function of Omega-3 essential fats is to actively participate in the production of powerful substances, like hormones, called prostaglandins. The latter regulates many physiological functions, from blood pressure and blood clotting, to the information transmitted to the nerves, inflammatory and allergic responses, functioning of the renal system and the gastrointestinal tract and the production of other hormones. For instance, the eicosapentaenoic acid and the docosahexaenoic acid are direct precursors of prostaglandins of the 3 series, considered to be beneficial because it reduces platelet aggregation andinflammation, while improving the blood circulation. The role of the EPA and DHA acids in the prevention of cardiovascular disease can be explained in part by the ability of these fatty acids to increase the production of beneficial prostaglandins.

Researchers have recently discovered an fatty organic product, derived from EPA (following the intervention of cellular enzymes), called Resolvin, that inhibits the proliferation and migration of inflammatory cells and of harmful chemical products in close proximity to the inflamed regions. Unlike the anti-inflammatorydrugs, such as aspirin or ibuprofen, the Resolvin within the body, derived from EPA acids, show no side effects on the gastrointestinal or cardiovascular system.

\section{Symptoms of deficiency in Omega-3 fatty acids}

Recent medical statistics show that over $90 \%$ of the population does not have a sufficient intake of essential Omega-3 fatty acids in their daily diet. Symptoms of deficiency in these nutrients are often confused with the clinical manifestations of other nutritional deficiencies or disorders. Signs and symptoms that the body sends if it does not take enough Omega-3 are: low physical strength, lack of concentration, tiredness, aches and pains.

There are three varieties of purslane, namely: green, gold, and a variety with reddish leaves. In table 1 are listed the important sources of Omega-3 fatty acids; the presence of these acids cause a low incidence of cancer and heart disease, eventually, in part because of the natural intake of Omega-3 fatty in the products with the purslane.

\section{Table 1}

VEGETAL SOURCES OF OMEGA-3 FATTY ACIDS ( $\mathrm{g} / 100 \mathrm{~g})$

\begin{tabular}{|c|l|c|}
\hline Category & \multicolumn{1}{|c|}{ Fruits/vegetables } & Amount (g) \\
\hline \multirow{5}{*}{ Low } & Avocados, California raw & 0.1 \\
& Broccoli & 0.1 \\
& Strawberries & 0.1 \\
& Cauliflower, raw & 0,1 \\
& Kale, raw & 0.2 \\
& Spinach, raw & 0.1 \\
& Peas, garden dry & 0.2 \\
& Cowpeas, dry & 0.3 \\
& Beans, navy, sprouted, cooked & 0.3 \\
& Corn, germ & 0.3 \\
\hline \multirow{5}{*}{ Medium } & Bean, common dry & 0.6 \\
& Leeks, freeze-dried, raw & 0.7 \\
& Wheat, germ & 0,7 \\
& Spirulina, dried & 0.8 \\
& Purslane & 0.9 \\
& Oat, germ & 1.4 \\
& Beachnuts & 1.7 \\
& Soybeans kemels, roasted & 1.5 \\
& Soybeans, green & 3.2 \\
\hline \multirow{5}{*}{ High } & Soybean oil & 6.8 \\
& Walnuts, Persian, English & 6.8 \\
& Wheat germ oil & 6,8 \\
& Butternuts & 8.7 \\
& Walnut oil & 10.4 \\
& Rapeseed oil & 11.1 \\
\hline \multirow{5}{*}{} &
\end{tabular}

Purslane is the best used green vegetable for human consumption as a rich source of minerals and Omega-3 fatty acids. Compared to the leaves of spinach, purslane leaves contain a high content of al pha-linolenic acid (18: 3 $\omega 3)$, alpha-tocopherol, ascorbic acid and glutathione.

Purslane has one of the highest levels of alpha-linolenic acid, which is an essential Omega-3 fatty acid for human nutrition as compared to any other green leafy vegetables. The leaves of purslane grown in the chamber of controlled and in the wild presented a greater amount of alphalinolenic fatty acid (18: $3 \omega 3$ ) than the spinach leaves. The highest amount ( $3.41 \mathrm{mg} / \mathrm{g}$ ) of alpha-linolenic acid was recorded in the growth chamber where the purslane and was cultivated, it was seven times higher than that in the leaves of spinach $(0.48 \mathrm{mg} / \mathrm{g})$.

\section{Edacious use}

-Purslane has no flavor; fleshy leaves have a refreshing taste, slightly spicy and astringent (a little citric) and their texture is both crispy and succulent.

-The leaves and young stems are a nice addition to salads. In Middle East there are prepared delicious salads of chopped purslane leafs, yogurt and various green vegetables (green cucumber, green pepper, etc.) as an accompaniment to roasted meat. Purslane is one of the famous ingredients in Lebanese salad Fattoush.

- Mature leaves are blanched and used as a vegetable. Cooking enhances their mucilaginous content, making them a good thickener for soups and stews. In Turkey, for example, the purslane is used to prepare stews of lamb and beans, while around the entire Mediterranean is used in soups. In Mexico, the purslane is cooked with pork, tomatoes and peppers (especially those of the chipotles variety). The purslane is also very suitable combined with spinach, olive oil and lemon juice. It is a high quality companion for the dishes prepared with beets, beans, cucumbers, eggs, cheese, potatoes, yogurt.

-Among other spices, it fits well with borage, chervil, cress (nasturtium), cow-cheese, cress, ruccola, watercress, parsley, mint, etc. (http://condimenteweb.ro).

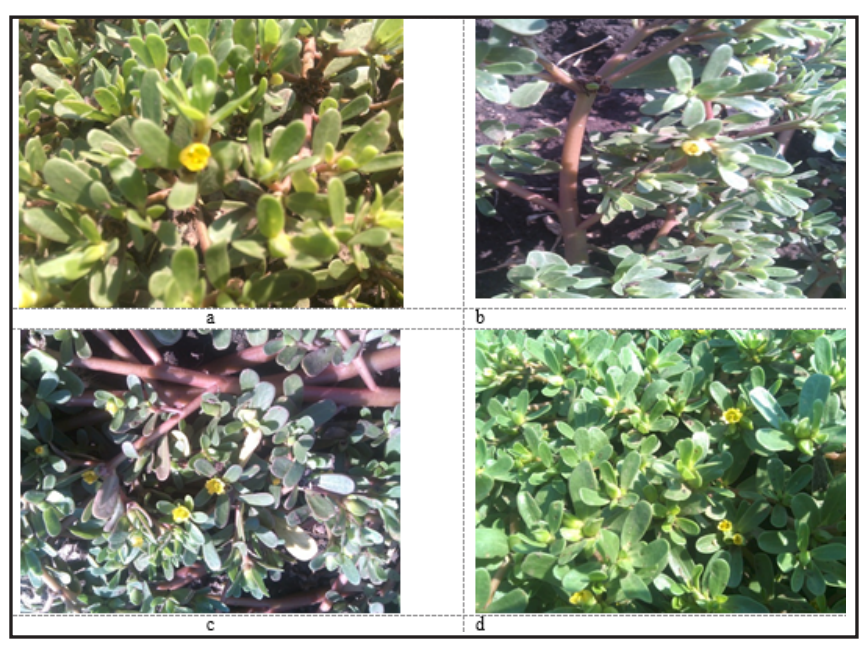

Fig.1 Portulaca oleracea [a, b, c, d] 


\section{Experimental part}

Materials and methods

In order to obtain the dried vegetal product of purslane (Portulaca oleraceea), after harvesting, the fresh vegetal product passes through the following stages (within SC Hofigal Export Import SA):

-sorting of the fresh vegetal product: is performed for removing foreign matter (parts of the same plant or parts of other plants and foreign materials of mineral origin).

- washing of the vegetal product. is performed using the $X Y-700$ vegetable material washing machine with drum made of stainless steel for removing any foreign mineral origin (dust, sand).

- drying of the vegetal product. after washing, the fresh vegetal product is introduced in the HG 25 hot air dryer which has been previously brought to a temperature of $400^{\circ} \mathrm{C}$. Drying is carried out over a period of $48 \mathrm{~h}$. After the drying process, hot air supply of the dryer is closed and the dried vegetal product is discharged.

The HG 25 dryer is provided with panel, electromechanical system in the feeding area, gear system, conveyor belt made of stainless steel, drying room, radiator, fan. The operating parameters of the HG 25 dryer equipment are: voltage $380 \mathrm{~V}$; hot air pressure: $1.5-3$ bar; temperature: $400^{\circ} \mathrm{C}$; time: $48 \mathrm{~h}$.

-grinding of the driedthe vegetal product: is performed using the MMC 2 mill for grinding plant material, which is made of stainless steel, provided with sliding elements on the side walls to remove the shaft port knife, lugs of the lid in the upper part of the mill, parts for catching the discharge bag at the bottom, sieve holder located inside the sidewalls, main shaft with 16 double-edged knives, arranged by 4 to 900 . Grinding of the dried plant product takes place as follows:

-the collection box for the chopped plantmaterial is fixed at the outlet of the mill;

-sieve no. $8000 \mathrm{~m}$ is being assembled;

-the mill for grinding the vegetal material is started acting the switch;

-the dried vegetable product is introduced in the MMC 2 mill feed funnel, gradually or in portions, so that a sudden supply of the mill does not lead to its blocking.

In order to determine the chromatographic profile of fatty oil in Portulaca oleracea it was used the chromatographic method (GC-MS) for the identification and dosing of fatty acid composition: it is performed according to the method of analysis developed by the European Pharmacopoeia, the currentedition.

\section{Equipment:}

-gas chromatograph coupled with mass spectrofotometer:

-refluxing installation.

Reagents:

-petroleum ether R;

-the sample to be analyzed: the oil as such;

-hydrochloric acid R in methanol, $0.5 \mathrm{M}$ solution;

-water R;

-isooctane R;

-heptane R;

-sodium sulfate $R$, anhydrous;

- test solution: $0.1 \mathrm{~g}$ of sample is weighted into a round bottom flask and is dissolved in $5.0 \mathrm{~mL}$ of ether petroleum $\mathrm{R}$ and $50 \mathrm{~mL}$ of ahydrochloric acid $\mathrm{R}$ in $0.5 \mathrm{M}$ methanol solution. It is then maintained at reflux under stirring and heating in the nest, at a temperature of about $65^{\circ} \mathrm{C}$ for $\mathrm{lh}$ (until there is no further notice of unmethylated drops of oil). The sample is cooled and passed into a separating funnel. The round-bottomed flask is washed with 30-40
$\mathrm{mL}$ of water $R$, then with $40 \mathrm{~mL}$ of isooctane $R$ and is added and the separatory funnel. The isooctane layer is washed with water $\mathrm{R}$ to neutral $\mathrm{pH}$. The iso-octane layer is separated, and switched over to anhydrous sodium sulfate $R$, to remove water and then is filtered;

- reference solution A: a calibration mixture is prepared with the composition described in the European Pharmacopoeia, the current edition, Chapter 2.4.22. Table 2.4.22.-1, the substances being dissolved in heptane $R$, thus:

Table 2

\begin{tabular}{|l|c|}
\hline Substances in the mixture & Amount $(\%, \mathbf{m} / \mathbf{m})$ \\
\hline Methyl laureate R & 5 \\
\hline Methylmyristate R & 5 \\
\hline Methyl palmitate R & 10 \\
\hline Methyl stearate R & 20 \\
\hline Methylarachidic R & 40 \\
\hline Methyl oleate R & 20 \\
\hline
\end{tabular}

Chromatographic system:

a) Gas chromatograph fitted with:

- detector MS (mass spectrometer);

- split injector;

- automatic injection system of the sample for analysis;

- automatic integration system of peak areas of the obtained chromatograms.

b) column:

- material: fused silica; lenght $30 \mathrm{~m}$, diameter $0.25 \mathrm{~mm}$;

- macrogol stationary phase 20000 R (film thickness $0.25 \mu \mathrm{m})$;

c) work conditions:

-carrier gas: helium $\mathrm{R}$, for chromatography;

-flow: $1.5 \mathrm{~mL} / \mathrm{min}$;

-split report: 1:60;

-temperature program:

Table 3

\begin{tabular}{|c|c|c|}
\hline Characteristic & Time (minutes) & Temperature $\left({ }^{\circ} \mathrm{C}\right)$ \\
\hline & $0-5$ & 160 \\
Column & $6.0-10.0$ & $160-200$ \\
& 10.0 & $200-225$ \\
\hline Injector & - & 250 \\
\hline Detector & - & 270 \\
\hline
\end{tabular}

Technical work

$1 \mu \mathrm{L}$ of reference solution $A$ and $1 \mu \mathrm{L}$ of test solution are injected. Retention times are recorded. Resolution: minimum 1.8 between the peaks determined by methyl oleate and methyl stearate in the chromatogram obtained with the reference solution $A$.

Identification: oil components in the sample are located by using MS spectra library in the range M/Z: 40-450. The limits range as follows: oleic acid ( $40-55 \%)$, linoleic acid, (26- 36\%), $\alpha$-linolenic acid $<0.5 \%$, palmitic acid (10 -20 $\%)$, stearic acid (4 - $8 \%)$.

\section{Results and discussions}

1. Chromatographic profile of fatty oil in Portulaca oleracea, plant harvested in September 2014

Qualitative Report Library Gas-Chromatograph GC - MS

Data File:

Current Data Path:

Sample Type:

Acquisition Date:

Run Time (min):

Vial: Purslane oil /from 05.09.14

Injection Volume $(\mu \mathrm{L}): 1.00$

C:|Xcalibur|DATA2|Fat oil $9 \|$

Unknown

9/5/2014 10:05:39AM

Calibration Level:

Instrument Method: C:|Xcalibur|DATA2|Fat

9|1mIOMEGA3152000FB. meth

Processing Method: C:|Xcalibur|DATA2l Fat oil 


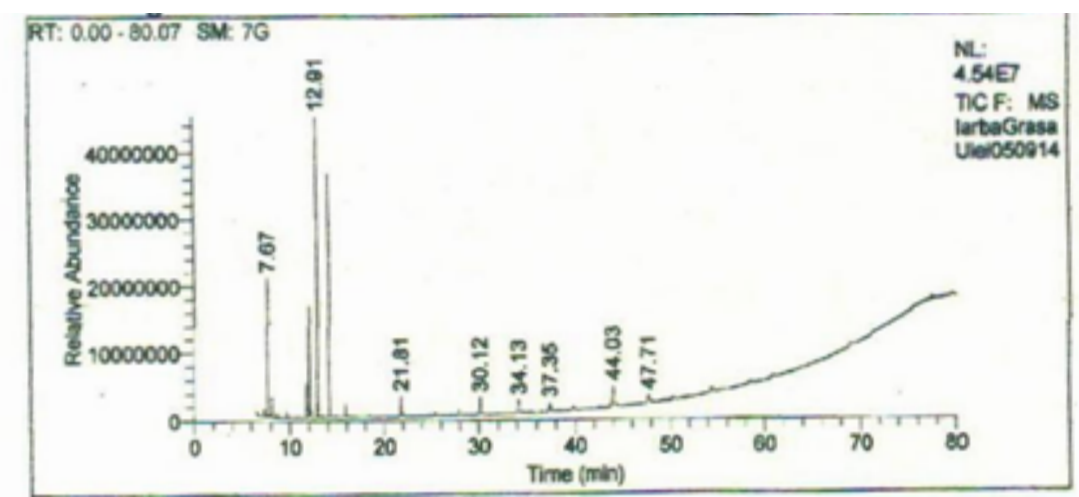

Fig.2. Chromatogram: Purslane oil

\begin{tabular}{|c|l|c|c|c|c|c|}
\hline No. & \multicolumn{1}{|c|}{ Compound name } & RT & $\begin{array}{c}\text { Area } \\
\%\end{array}$ & $\begin{array}{c}\text { Peak } \\
\text { area }\end{array}$ & $\begin{array}{c}\text { Peak } \\
\text { height }\end{array}$ & S/N \\
\hline 1. & Palmitic C16:0 & 7.67 & 12.35 & 71117379 & 18642779 & 10965.15 \\
\hline 2. & Stearic C18:0 & 11.74 & 3.47 & 19994144 & 4696064 & 2762.09 \\
\hline 3. & Oleic C18:1 & 12.04 & 10.73 & 61772557 & 15426807 & 9073.61 \\
\hline 4. & Linoleic $\gamma$ C18:2 & 12.91 & 28.72 & 165386823 & 40947710 & 24084.27 \\
\hline 5. & Linolenic $\alpha$ C18:3 & 14.16 & 22.95 & 132159759 & 32888611 & 19344.14 \\
\hline 6. & Behenic C22:0 & 21.81 & 3.98 & 22898744 & 2941177 & 1729.92 \\
\hline 7. & Lignoceric C24:0 & 30.12 & 4.23 & 24352107 & 2532264 & 1489.41 \\
\hline 8. & Octaethylene glycol & 34.13 & 3.88 & 22315831 & 1887804 & $1110 / 35$ \\
\hline 9. & Octaethylene glycol & 37.35 & 2.78 & 15983424 & 1273614 & 749.10 \\
\hline 10. & Octaethylene glycol & 44.03 & 6.91 & 39796113 & 2927671 & 1721.97 \\
\hline
\end{tabular}

Table 4

Chromatographic profile of fatty oil in Portulaca oleracea, plant harvested in September 2014 shows a content in fatty acids in the following decreasing order of its abundance, as follows:

Linoleic $\gamma$ C18:2> Linolenic $\alpha$ C18:3> Palmitic C16:0> Oleic C18:1> Octaethylene glycol> Lignoceric C24:0> Behenic C22:0> Stearic C18:0.

Chromatographic profile of fatty oil in Portulaca oleracea, plant harvested in July 2015

Qualitative Report Library Gas-Chromatograph GC - MS

Data File: PURSLANE OIL AROMA
Current Data Path:

Sample Type:

Acquisition Date:

Run Time ( $\min )$ :

Vial:

Injection Volume $(\mu \mathrm{L}): 1.00$

Calibration Level:

Instrument Method: $\quad C: \backslash X \mathrm{X}$ a $\mid$ ibu $\backslash \backslash$ DATA $2 \backslash F a t$

oil11|1mlOMEGA315200oFB.meth

Processing Method: C:|Xcalibur|DATA2|Fat oil

10l22NewSoft10pkBB V

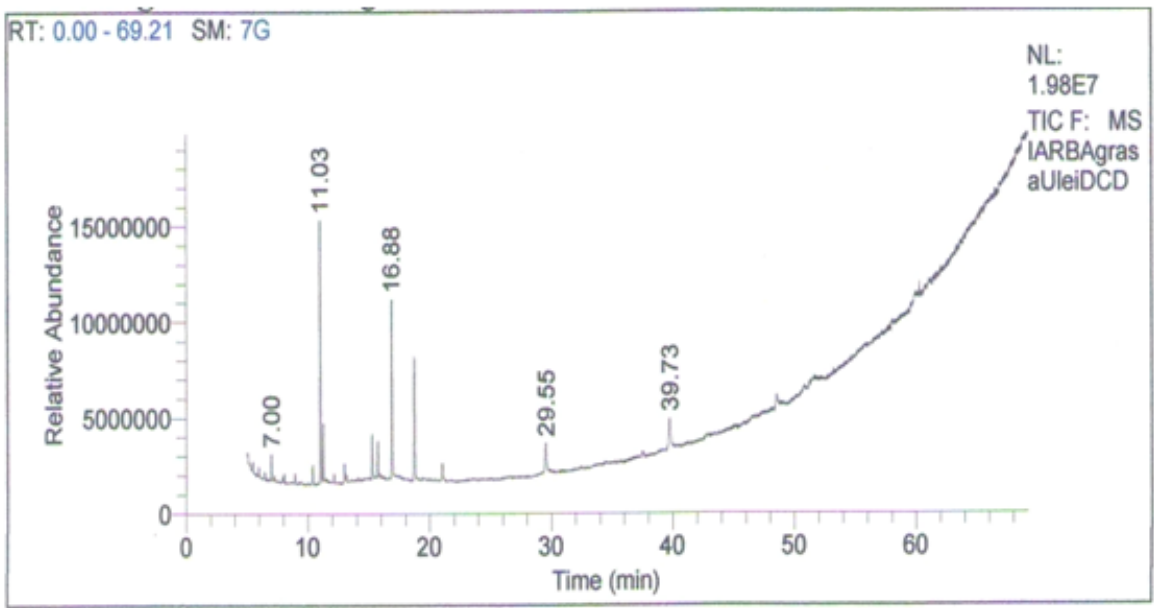

Fig.3. Chromatogram: Purslane oil DCD

\begin{tabular}{|c|l|r|r|r|r|r|}
\hline No. & \multicolumn{1}{|c|}{ Compound name } & \multicolumn{1}{c|}{ RT } & \multicolumn{1}{c|}{$\begin{array}{c}\text { Area } \\
\%\end{array}$} & \multicolumn{1}{c|}{$\begin{array}{c}\text { Peak } \\
\text { Area }\end{array}$} & \multicolumn{1}{c|}{$\begin{array}{c}\text { Peak } \\
\text { Height }\end{array}$} & \multicolumn{1}{c|}{ S/N } \\
\hline 1. & Palmitic C16:0 & 11.03 & 22.79 & 44389992 & 12264614 & 4826.22 \\
\hline 2. & Octaethylene glycol & 11.26 & 5.60 & 10904771 & 2836824 & 1116.31 \\
\hline 3. & Stearic C18:0 & 15.29 & 4.62 & 9006212 & 2160348 & 850.11 \\
\hline 4. & Oleic C18:1 & 15.74 & 4.41 & 8597755 & 1815668 & 714.48 \\
\hline 5. & Linoleic 7 C18:2 & 16.88 & 21.41 & 41702183 & 8704515 & 3425.29 \\
\hline 6. & Linolenic $\alpha$ C18:3 & 18.74 & 17.14 & 33391578 & 6169749 & 2427.84 \\
\hline 7. & Arachic C20.0 & 21.05 & 3.35 & 6528791 & 914518 & 359.87 \\
\hline 8. & Behenic C20:0 & 29.55 & 7.52 & 14646225 & 1524510 & 599.91 \\
\hline 9. & Lignoceric C20:0 & 39.73 & 9.13 & 17787096 & 1544868 & 607.92 \\
\hline 10. & Octaethylene glycol & 48.57 & 4.03 & 7854646 & 723303 & 284.63 \\
\hline
\end{tabular}

Table 5 
Chromatographic profile of fatty oil in Portulaca oleracea, plant harvested in July 2015 showsa content in fatty acids in the following decreasing order of its abundance, as follows:

Palmitic C16:0> Linoleic $\gamma$ C18:2> Linolenic $\alpha$ C18:3> Lignoceric C24:0> Behenic C22:0> Stearic C18:0> Oleic C18:1> Octaethylene glycol> Arachic C20.0.

Chromatographic profile of fatty oil in Portulaca oleracea, plant harvested in August 2016 Hofigal/ Alexandria

Qualitative Report Library Gas-Chromatograph GC - MS Data File: 01.07.16
14!

Current Data Path:

Sample Type:

Acquisition Date:

Run Time ( $\mathrm{min})$ :

Vial:

Injection Volume (1

Calibration Level:

Instrument Method: C:|Xcalibur|DATA2|Fatoil 12/1ml

OMEGA3152500Farm.meth

Processing Method: C:|Xcalibur|DATA2|Fat oil $12 \mid 22$ SoftNou 10pkBB V

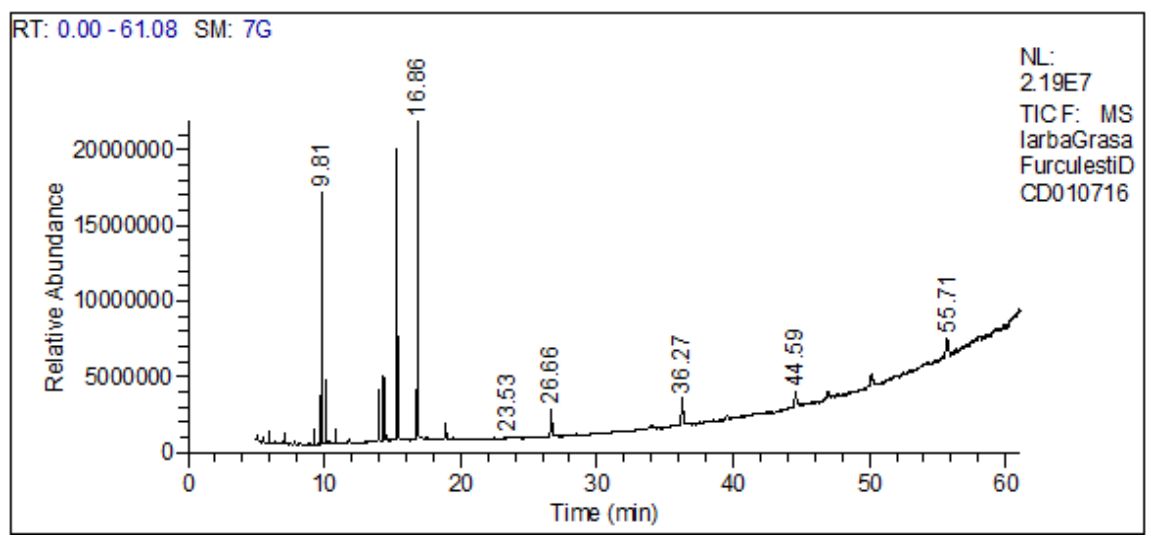

Fig. 4. Chromatogram: Purslane Hofigal/ Alexandria, Furculesti DCD

\begin{tabular}{|c|l|r|r|r|r|r|}
\hline No. & \multicolumn{1}{|c|}{ Compound name } & \multicolumn{1}{c|}{ RT } & \multicolumn{1}{c|}{ Area \% } & \multicolumn{1}{c|}{ Peak Area } & \multicolumn{1}{c|}{$\begin{array}{c}\text { Peak } \\
\text { Height }\end{array}$} & \multicolumn{1}{c|}{ S/N } \\
\hline 1. & Palmitic C16:0 & 9.81 & 17.08 & 50689257 & 14794604 & 9109.20 \\
\hline 2. & Stearic C18:0 & 13.99 & 3.70 & 10975258 & 3027276 & 1863.93 \\
\hline 3. & Oleic C18:1 & 14.38 & 4.52 & 13416004 & 3779391 & 2327.01 \\
\hline 4. & Linoleic $\gamma$ C18:2 & 15.34 & 21.88 & 64929669 & 17421797 & 10726.79 \\
\hline 5. & Linolenic $\alpha$ C18:3 & 16.86 & 27.94 & 82941020 & 19463104 & 11983.65 \\
\hline 6. & Behenic C20:0 & 26.66 & 5.04 & 14961490 & 1783426 & 1098.08 \\
\hline 7. & Lignoceric C24:0 & 36.28 & 5.46 & 16205158 & 1741672 & 1072.37 \\
\hline 8. & Tricosanol & 44.60 & 3.80 & 11286730 & 990496 & 609.86 \\
\hline 9. & Hexacosanol & 55.70 & 5.79 & 17186301 & 1287768 & 792.89 \\
\hline
\end{tabular}

Table 6

Chromatographic profile of Portulaca oleracea fatty oil, plant harvested in August 2016 Hofigal / Alexandria shows a content in fatty acids in the following decreasing order of its abundance, as follows:

Linolenic $\alpha$ C18:3> Linoleic $\gamma$ C18:2> Palmitic C16:0> Hexacosanol> Lignoceric C24:0> Behenic C22:0> Oleic C18:1> Tricosanol> Stearic C18:0

Chromatographic profile of fatty oil inPortulaca oleracea, plant harvested in August 2016 Hofigal/ Bucharest

Qualitative Report Library Gas-Chromatograph GC - MS

Data File: $\quad$ Purslane oil CPCasa 10.08.2016
141

Current Data Path:

Sample Type:

Acquisition Date:

Run Time (min):

Vial:

Vial: $\quad 191$
Injection Volume $(\mu \mathrm{L}): 1.00$

C:|XCALIBURIDATA2|FAT OIL

Calibration Level:

Instrument Method: C:|Xcalibur|DATA2|Fat oil 12|1mIOMEGA315250oFarm. meth

Processing Method:

12/22SoftNou 10pkBB V
Unknown

8/22/2016 10:27:38 AM

58.33

C:|Xcalibur|DATA2|Fat oil

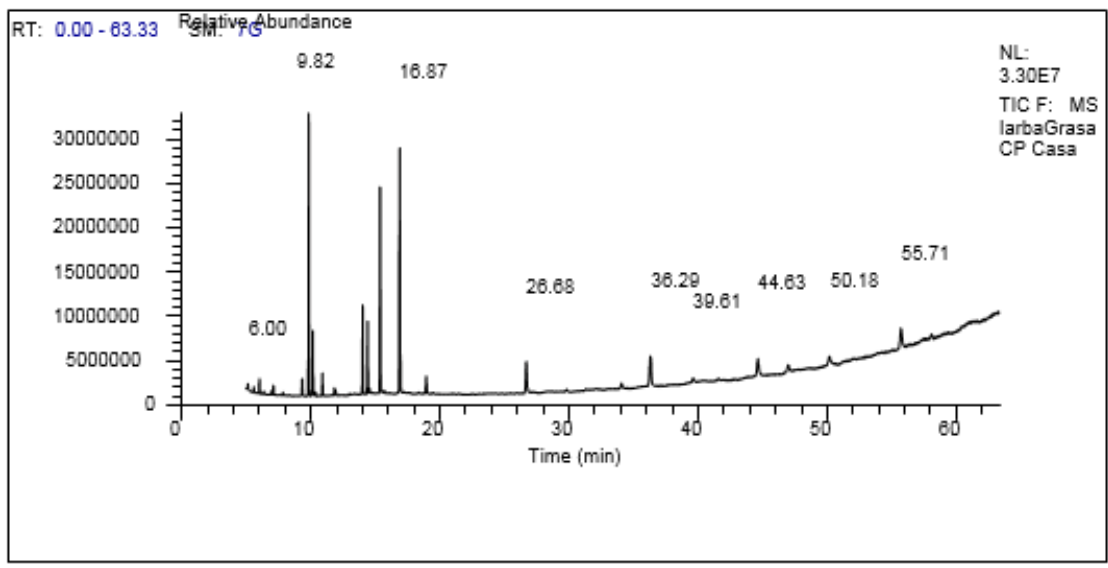

Fig.5. Chromatogram: Purslane oil Hofigal/ Bucharest 


\begin{tabular}{|c|l|r|r|r|r|r|}
\hline No. & \multicolumn{1}{|c|}{ Compound name } & RT & \multicolumn{1}{c|}{$\begin{array}{c}\text { Area } \\
\%\end{array}$} & \multicolumn{1}{c|}{$\begin{array}{l}\text { Peak } \\
\text { Area }\end{array}$} & \multicolumn{1}{c|}{$\begin{array}{c}\text { Peak } \\
\text { Height }\end{array}$} & S/N \\
\hline 1. & Palmitic C16:0 & 9.82 & 24.40 & 97738693 & 284012214 & 14915.65 \\
\hline 2. & Stearic C18:0 & 14.00 & 6.65 & 31867798 & 8999900 & 4726.54 \\
\hline 3. & Oleic C18:1 & 14.39 & 5.39 & 25818405 & 7305332 & 3836.59 \\
\hline 4. & Linoleic 7 C18:2 & 15.35 & 16.80 & 80495948 & 21274313 & 11172.77 \\
\hline 5. & Linolenic $\alpha$ C18:3 & 16.87 & 23.46 & 112430448 & 26081383 & 13697.33 \\
\hline 6. & Behenic C20:0 & 26.68 & 5.61 & 26873701 & 3478003 & 1826.57 \\
\hline 7. & Lignoceric C24:0 & 36.30 & 6.78 & 32505233 & 3338196 & 1753.14 \\
\hline 8. & Tricosanol & 44.62 & 4.57 & 21874399 & 1940109 & 1018.90 \\
\hline 9. & Hexacosanol & 55.71 & 5.33 & 25516492 & 21984494 & 1154.60 \\
\hline
\end{tabular}

Table7

Chromatographic profile of Portulaca oleracea fattyoil, plant harvested in August2016 Hofigal / Bucharestshows a content in fattyacids in the following decreasing order of its abundance, as follows:

Palmitic C16:0> Linolenic $\alpha$ C18:3> Linoleic $\gamma$ C18:2> Lignoceric C24:0> Stearic C18:0> Behenic C22:0> Oleic C18:1> Hexacosanol> Tricosanol.

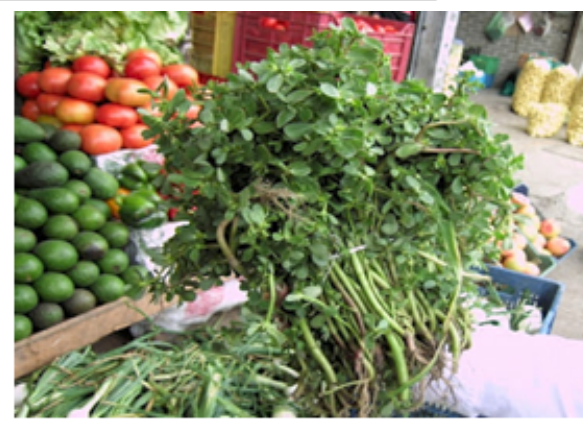

Fig. 6. Portulaca oleracea

Table 8

COMPARATIVE STUDY OF THE CHROMATOGRAPHIC PROFILE OF THE PLANT HARVESTED IN THREE CONSECUTIVE YEARS IN THE SAME AREA, IN JULY, AUGUST, SEPTEMBER

\begin{tabular}{|c|l|c|c|c|c|}
\hline No. & $\begin{array}{c}\text { Component name of the } \\
\text { fatty oil }\end{array}$ & $\begin{array}{c}\text { Content in the } \\
\text { plant from } \\
\mathbf{0 9 . 2 0 1 4}\end{array}$ & $\begin{array}{c}\text { Content in the } \\
\text { plant from } \\
\mathbf{0 7 . 1 0 1 5}\end{array}$ & $\begin{array}{c}\text { Content in the plant } \\
\text { Hofigal Alexandria } \\
\text { from 08.2016 }\end{array}$ & $\begin{array}{c}\text { Content in the plant } \\
\text { Hofigal Bucharest } \\
\text { from 08.2016 }\end{array}$ \\
\hline 1 & Palmitic C16:0 & 12.35 & 22.79 & 17.08 & - \\
\hline 2 & Octaethylene glycol $\alpha$ & 3.88 & 5.60 & - & - \\
\hline 3 & Stearic C18:0 & 3.47 & 4.62 & 3.70 & 6.65 \\
\hline 4 & Oleic C18:1 & 10.73 & 4.41 & 4.52 & 5.39 \\
\hline 5 & Linoleic 7 C18:2 & 28.72 & 21.41 & 21.88 & 16.80 \\
\hline 6 & Linolenic $\alpha$ C18:3 & 22.95 & 17.14 & 27.94 & 23.46 \\
\hline 7 & Arachic C20:0 & - & 3.35 & & 5.61 \\
\hline 8 & Behenic C20:0 & 3.98 & 7.52 & 5.04 & 6.78 \\
\hline 9 & Lignoceric C20:0 & 4.23 & 9.13 & 5.46 & - \\
\hline 10 & Octaethylene glycol $\beta$ & 2.78 & 4.03 & - & - \\
\hline 11 & Octaethylene glycol $\gamma$ & 6.91 & - & - & 4.57 \\
\hline 12 & Tricosanol & - & - & 3.80 & 5.33 \\
\hline 13 & Haxacosanol & - & - & 5.79 & \\
\hline
\end{tabular}

From table 8 it results that:

-the content in Omega-3 (Linolenic $\alpha$ C18:3) was the highest in the vegetal product harvested in August, respectively in September;

-the content in Omega- 6 (Linoleic $\gamma$ C18:2)was the highest in the vegetal product harvested in September, respectively in August;

-the lowest content in Omega- 3 (Linolenic $\alpha$ C18:3) was found in the vegetal product harvested in July;

-For the purpose in this study, the optimum time of harvesting the native plant Portulaca oleracea as natural plant source of Omega-3 / Omega-6 is August-September.

\section{Conclusions}

It was found the possibility of dosing fatty oil in the dry plant ( 2.20-2.24\%), while in the

fresh plant the oil is in traces.

The presence of fatty acids Omega 3, 6 and 9 in the composition of analyzed Portulaca samples [essential fatty acids Omega-3 (Linolenic C18: 3); Omega-6 (Linoleic C18: 2) and Omega-9 (Oleic C18: 1)] meet the above functions and its manifest these actions when the plant is an active source of raw material source for drugs, food supplements and cosmetics.The presence of this plant on almost all types of relief in our country, where it grows without large claims, is a source of native raw material to a very low cost, which contributes to improving the production costs, according to key concepts in business, efficiency by efficiency.

As a significant source of Omega-3 oils, Portulaca oleracea could bring considerable health benefits for vegetarian diets and other areas where the consumption of fish oils is excluded. Scientific analysis of its chemical components showed that this common plant has a less frequently encountered nutritional value, making it one of the most important potential food for future.

Also, the presence of a high content of antioxidants (vitamins A and C, alpha-tocopherol, beta carotene and glutathione), fatty acids Omega-3, 6 and 9 , due to its healing effects wound and antimicrobial properties, and its traditional use in the local treatment of the inflammatory conditions suggests that the purslane (Portulaca oleracea) is a very likely candidate and also as a useful cosmetic ingredient.

\section{References}

1. LIU, L., HOWE P., ZHOU Y-F, XU Z-Q, HOCART C, ZHANG R., Fatty acids and $\beta$-carotene in Australian purslane (Portulaca oleracea) varieties. Journal of Chromatography A., 893(1), 2000, pp. 207-213. 2. SIMOPOULOSA.P., NORMAN H.A., GILLASPY J.E., Purslane in human nutrition and its potential for world agriculture. World Review of Nutrition and Dietetics,77, 1995, pp. 47-74. 
3. OLIVEIRA I, VALENTAO P, LOPES R, ANDRADE P.B., BENTO A., PEREIRA J .A., Phytochemical characterization and radical scavenging activity of Portulaca oleraceae $L$. leaves and stems. Microchemical Journal, 92(2), 2009, pp.129-134.

4. SIMOPOULOS A.P., Omega-3 fatty acids and antioxidants in edible wild plants. Biological Research, 37(2), 2004, pp. 263-277.

5. WHELAN J., RUST C., Innovative dietary sources of n-3 fatty acids. Annual Review of Nutrition, 26, 2006, pp. 75-103.

6. UDDIN M.K., JURAIMI A.S., HOSSAIN M.A., ANWAR F., ALAM M.A., Effect of salt stress of Portulaca oleracea on antioxidant properties and mineral compositions. Australian J ournal Crop Science, 6, 2012, pp.1732-1736.

7. RAICIU, A. D., POPESCU ,M., IVOPOL, G. C., BORDEI N., ALEXANDRU, G., CRISAN, I., MANEA, S., DIMA, S. O., Rev. Chim. (Bucharest), 67, no. 12, 2016, pp.2449-2453.

8. SIRIAMORNPUN S, SUTTAJIT M., Microchemical components and antioxidant activity of different morphological parts of thai wild purslane(Portulaca oleracea)Weed Science, 58, (3), 2010, pp. 182188.

9. SIMOPOULOSA.P., NORMAN H.A., GILLASPY J.E, DUKE J.A., Common purslane: a source of omega-3 fatty acids and antioxidants. Journal of the American College of Nutrition, 11(4), 1992, pp. 374-382.

10. LIM Y.Y, QUAH E.P.L. Antioxidant properties of different cultivars of Portulaca oleracea. Food Chemistry, 103(3), 2007, pp. 734-740.

11. ALAM M.A., JURAIMI A.S., RAFII M.Y., Evaluation of antioxidant compounds, antioxidant activities and mineral composition of 13 collected purslane (Portulaca oleracea L.) accessions. BioMed Research International, 10, 2014, p.296.

12. SIMOPOULOS A.P., TAN D-X, MANCHESTER L.C., REITER R.J., Purslane: a plant source of omega-3 fatty acids and melatonin. Journal of Pineal Research, 39(3), 2005, pp. 331-332.

13.AHMED A.I M., IBRAHIM A.N., MOHAMED D.A., SALEH A.Q., Neuronal activities of portulaca oleracea in adult rats, J ournal of medicinal plant Research, 6(16), 2012, pp.3162-3168.

14. LEE A.S., Lee Y.J ., LEE S.M., YOON J. J., KIM J.S., KANG D.G., LEE H. S., Portulaca oleracea ameloriates diabetic vascular inflammation and endothelial. dysfunction in $\mathrm{db} / \mathrm{db}$ Mice. Evidence- based complementary and alternative medicine, 2012, pp. 1-9.

15. DWECK A. C., Purslane (portulaca oleracea) - the global panacea. Personal care magazine, 2(4), 2001, pp. 7-15.

17. BEAULIEU D., Edible Landscaping With Purslane; About.com, 2013.
16. Cherukuri Vidyullatha Chowdhary, Anusha Meruva, Naresh K., Ranjith Kumar A. Elumalai. A review on phytochemical and pharmacological profile of portulaca oleracea Linn. (Purslane). Int. J. Res. Ayur. Pharm., 4(1), 2013, pp. 34-37.

17. FOSTER, S., DUKE J. A., A Field Guide to Medicinal Plants and Herbs. 2nd Ed. Boston: Houghton Mifflin Company, 2000.

18. GRIEVE, M., A Modern Herbal - the medicinal, culinary, cosmetic and economic properties, cultivation and folklore of herbs, grasses, fungi, shrubs and trees with all their modern scientific uses. Tiger Books International, London, 1998.

19. JAGAN R., MALLIKARJUNA R. B., KAVITHA R., SUBASH KR., BINOYVARGHESE C., Evaluation of anti-arthritic activity of pet-ether extract of portulaca oleracea, International J ournal of Applied Biology and Pharmaceutical Technology, 3(3), 2012, pp. 144-148.

20. KAMAL U. M., ABDUL S.J ., EAQUB A. M., MOHD R.I., Evaluation of Antioxidant properties and mineral composition of purslane ( portulaca oleracea ) at different growth stages, Int. J. Mol. Sci., 13, 2012, pp. 10257-10267.

21. LEUNG, A.Y., FOSTER, S., Encyclopedia of Common Natural Ingredients used in food, drugs and cosmetics. 2nd. edition. John Wiley 1996.

22. RAMESH L., HANUMANTAPPA N. B., Phytochemical and antimicrobial activities of portulaca oleracea. J ournal of Pharmacy Research,4 (10), 2011, pp.3553-3555.

23.***United States Department of Agriculture, Agricultural research service, National Nutrient Database for Standard Reference Release 26 2011. Basic report:11427, purslane Raw

24. *** INMA - Metodologie pentru experimentarea masinii de taiat plante medicinale si aromatice (MET-01), Bucuresti, 2011.

25. EGEA-GILABERT C., RUIZ-HERNÁNDEZ V., PARRA A., FERNANDEZ J.A., Characterization of purslane (Portulaca oleracea L.) accessions: Suitability as ready-to-eat product, Scientia Horticulturae no. 172, 2014, pp. 73-81.

26.*** Farmacopeea Romana, editia a X-a, Editura medicala, Bucuresti, 2008.

27.*** United State Pharmacopoeia USP 34- NF 29, US pharmacopoeia, Rockville, Maryland, USA, 2010.

28.*** European Pharmacopoeia, 8th Edition, Council of Europe, Strasbourg, 2014.

$\overline{\text { Manuscript received: } 6.06 .2017}$ 